\title{
Public University Modes of COMMUNICATIONS: A STUDY OF STUdENT PREFERENCES
}

\author{
Teri Root, David C. Wyld, Joseph Palmisano and Maya Weber \\ Department of Marketing and Supply Chain Management, Southeastern Louisiana \\ University, Hammond, La
}

\begin{abstract}
While there has been a plethora of research in higher education concerning how instructors communicate directly with students in their classes, there has been a paucity of work regarding the subject of the present study, which is how do - and how should - universities most effectively communicate with current students about non-instructional information and news. The present study took place at a publicly-funded, regional state university in the Southeast United States and incorporated an extensive email sampling of students. The findings showed that today's largely Gen Z students have important communication preferences that need to be taken into consideration by university leaders as they consider how to best communicate non-instructional messages to them. The study has important implications for university leaders to consider as to how to most effectively make use of text and email, as well as social media platforms, in their communications strategy for non-instructional matters and university news.
\end{abstract}

\section{KEYWORDS}

Communication, Organizational Communications, University Communications, Universities, Public Universities, Communication Preferences, Social Media, College Students, Generational Differences, Gen Z,

\section{INTRODUCTION}

Today, the modes of communication are vast and seemingly ever changing. Every week, a new communication tool - a new social network, a new video platform, a new app, etc. - is introduced into the marketplace. These new communication tools create great opportunities for businesses and organizations in terms of reaching customers and various stakeholders in new and different ways and in manners far different than even in the recent past. However, the explosion of communication modes also presents challenges in that the new tools and platforms only add more choices to what is an increasingly cluttered media market, with much competition for people's attention today. Thus, the opportunity - and the conundrum - for all organizations today - large and small, public and private alike - is to determine which modes of communication are the most effective at reaching various target audiences.

The choice of communication modes is certainly an issue today for the leaders of all educational institutions, including institutions of higher learning. There is quite a bit of research on how colleges and universities may more effectively communicate with and recruit prospective students. There is also a great deal of research concerning effective communication between instructors and students at all educational levels including higher education. And while there has been a plethora of research in higher education concerning how instructors communicate directly with students in 

effectively communicate with current students about non-instructional information and news?

This study attempts to at least partially address that gap in the literature. This paper presents an empirical study which investigated which modes of communication current students report using most often to stay abreast of university news. Traditional modes of communication, as well as social media platforms and digital modes, were investigated. Students were also asked how likely they would be to use newer forms of communication to stay informed regarding campus news.

\section{LiterATURE REVIEW}

For years, millennials have dominated the student populations of college campuses. But a new generation of college students are entering freshman classes on university campuses. While this generation is known by a number of different names, the most prevalent is Generation $\mathrm{Z}$ or simply Gen Z. Gen Z are broadly defined as people born between 1996 and 2010, but Pew Research more recently defined Gen $\mathrm{Z}$ as anyone born from 1997 onward [1]. By whichever definition is used, this Generation $\mathrm{Z}$ comprises the vast majority of today's traditional age undergraduate student population [2].

The following literature review reports information known about the communication/media preferences and habits of Gen Zers.

\subsection{Traditional Media}

In a recent survey of College Media Association members, the most dominant form of student media present on university campuses was newspapers. Newspapers were reported to be present by $89.6 \%$ of the respondents [3]. While things may have changed in the last few years, one study found that the college newspaper continues to be read by a majority of students. This study reported that $53 \%$ of student respondents indicated that they read their college printed newspaper at least weekly. Sixty-four percent indicated that they had read the campus paper within the past two weeks [4]. In contrast, a more recent study found that Gen $\mathrm{Z}$ most frequently get their news from social media and only $6 \%$ read newspapers every day and 52\% never read newspapers for news [5]. The latter study focused on newspapers in general and not campus newspapers in particular so it has been yet to be seen if Gen $\mathrm{Z}$ students are continuing to read campus papers for university news.

It is hard to estimate the number of "college radio stations" for a number of reasons. The term college radio is not clearly defined. In general, a radio station operated on college campuses with some level of student participation could be considered a "college station". Not all stations are licensed so lists of FCC licensed radio stations cannot be relied upon. [6] lists 457 college stations. In a survey of College Media Association members, $68.9 \%$ reported that student radio stations were present on their campuses [7]. There is little information available with respect to whether Gen $\mathrm{Z}$ students are listening to their college stations. There is evidence that there are Gen $\mathrm{Z}$ audio listeners. A recent study found that over half (55\%) of U.S. 13-24 year olds listen to AM/FM daily which is a reach slightly more than streaming (53\%). They listen to AM/FM radio while in their cars. But they spend more time listening to audio at home than in their cars and streaming audio dominates as an audio source with Spotify being most popular [8].

Like campus newspaper and radio stations, the number of university-run television stations is difficult to estimate. In the previously mentioned study of College Media Association members, only $42.9 \%$ reported television stations to be present on their campuses [9]. It is unknown whether 
International Journal of Managing Public Sector Information and Communication Technologies (IJMPICT) Vol. 12, No.1, March 2021

students are using campus television stations to keep updated on campus news but there is evidence that they are not using television in general to get their news [10].

\subsection{Websites and E-mail}

It would be difficult to imagine a university operating without a website or e-mail system today. The question is not whether these are available to Gen $\mathrm{Z}$ students but rather how they use them. Most relevant to this study, is how current rather than prospective students use their university's website and whether they use it to get campus news and updates. One source found that current students do stay connected with their university through the website especially on their mobile devices. This same source reported that $90 \%$ have accessed college websites on two or more devices. The vast majority $(73 \%)$ reported using the website to access student portals while only a small percentage (12\%) reported using it to research news and events [11].

There is mixed information with respect to the use of e-mail by Gen $\mathrm{X}$ students and prospective students. One source reported that for Gen X students e-mail is the least preferred method of communication and that they prefer texting but this was with respect to admissions [12]. In communicating with businesses, e-mail was the preferred method of communication by baby boomers while the least preferred by Gen Zers [13]. [14] Found that Gen Z students do not like email. They think it is too formal and the response time is too slow. They also associate e-mail with their parents and other adults. It is comparable to what office memos and snail mail used to be. In contrast, another study reported that $81 \%$ of Gen $\mathrm{Z}$ respondents check their e-mail at least once a day. Most report that they use e-mail for personal communication $(64.9 \%)$ and less so for school (19.3\%) and work (14.4\%) [15].

A study done by Bowling Green State University found that $85 \%$ of the students surveyed check their university email every day. Whether they open the email depends on the sender. If they see it is sent by a faculty member, they are "highly likely to read it." They don't always read emails from student organizations. Seventy-two percent avoid opening these emails treating them like "spam." Emails from the university/academic departments and academic advisors were also not always read (54\% and 39\% respectively) [16]. Several other studies support the results about instructor-student e-mail communications but they do not address communications from the university thereby lending less insight for this study. [17, 18]. Others suggest that Gen Z students with their pragmatic natures and their desires to succeed will learn to monitor e-mail when they realize that important information is being delivered that way [19].

\subsection{Social Media}

Facebook is no longer the preferred social media platform among teens ages 13 to 17 . As one student put it, Facebook lost its appeal because it went to the adults [20]. Although when following others, Facebook, at least a few years ago, had an edge over the other platforms [20]. This may be changing as Pew Research Institute found that utilization by teens of three online platforms, YouTube, Instagram, and Snapchat, outpaced that of Facebook [21]. Other studies have supported these findings for older Gen Zers as well. One study found that a large percentage of people between 13 and 21 years of age in the U.S. use Instagram (65\%) and YouTube (62\%) on a daily basis [22].

Gen Z social media users may use different platforms for different purposes such as showing their aspirational selves on Instagram, sharing real-time moments on Snapchat, getting news on Twitter, and finding information on Facebook [23]. They use YouTube to keep them informed and knowledgeable, to relieve stress, and to be entertained [24]. A recent study by Pearson and Harris 
International Journal of Managing Public Sector Information and Communication Technologies (IJMPICT) Vol. 12, No.1, March 2021

Poll found that Gen $\mathrm{Z}$ ranked YouTube and video as preferred methods of learning over lectures, in-person peer activities, learning applications and books [25]. Ipsos also found that Gen $\mathrm{Z}$ teens felt that YouTube helped them become more knowledgeable and prepared for the future [26]. There is information in the literature that addresses the use of YouTube to recruit students or to teach students but little is available in terms of how effective YouTube is for communicating with current students about campus matters outside the classroom.

\subsection{Texts and Apps}

Smartphones have been in the hand of Gen Zers for years. Twenty-five percent had their own smartphone before the age of 10 [27]. While millennials have often been referred to as digitally native, Gen $\mathrm{Z}$ can be more aptly described as mobile and app-native [28]. Consistently, source after source reports that texting is a more preferred method of communication for Gen $Z$. "Texting has become a prominent mode for communication and widely popular among Generation $\mathrm{Z}$ students due to the ability to send and receive messages frequently and from almost any location" [29]. An international study by Live Person found that $75 \%$ of the American Gen Z and Millennials would prefer to communicate via text than on the phone [30]. It may be that there is the expectation that texting is like a real-time conversation. You send a text and expect a quick and immediate reply [31].

Federal law has required colleges and universities to have an emergency notification system since the 1990s. However, after the Virginia Tech shootings in 2007, many institutions strengthened their systems including the addition of text alerts [32]. Beyond emergency alerts, university admission offices are beginning to utilize text messaging to recruit new students. University Business reports that incoming college students and their parents find text messages about important enrollment information to be helpful [33]. Admissions offices may text students and parents with helpful information such as application reminders, new student orientation notifications, campus tour reminders, scholarship opportunities, and responses to admission questions [33]. Evidence from a text messaging experiment supports the usefulness of texting in recruitment. Text outreach to prospective students significantly increased college enrollment. Texting both students and parents did not, however, increase the effectiveness of this recruitment approach [34]. It is not known whether current Gen Z students are interested in receiving general campus news and updates via text messages.

University mobile apps could be used to keep students engaged both inside and outside the classroom. Since engagement is a key to ultimately completing a college degree, communicating with Gen $\mathrm{Z}$ students in the way that they prefer could be a tool to achieving student success [35]. "Apps like Connected Campus send helpful reminders to let students focus on what they need to do each day. By providing quick access to event calendars and to-do checklists, students can be better positioned to keep appointments and turn in work on time" [36]. Apps may also provide additional services under the same umbrella. [36] Also reports "These apps allow for the creation of forums where students can discuss study resources, arrange get-togethers, buy and sell used books, or just look for a sympathetic ear." The sense of community associated with applications may aid campus personnel better understand what students desire and the questions they may have. A case study reported by Texas A\&M at Galveston provides evidence that Gen Z students are interested in university-based apps. After implementing a mobile app, they found $91.7 \%$ of new students downloaded the app, registered, and were active on it. Furthermore, after surveying incoming students on the benefits of the app, they found that $83 \%$ reported that the app helped them get off to a good start, $96 \%$ agreed that the app helped them feel like they belonged, and $71 \%$ felt that the app helped them meet other students [37]. 
In summary, this study will investigate how current Gen Z students stay informed of campus events and news. Do they utilize traditional sources, university websites, read their e-mail messages, and/or follow their university on different social media platforms and YouTube? Since fewer universities are utilizing newer and popular Gen $\mathrm{Z}$ platforms like SnapChat, Gen Z respondents will also be asked their interest in using this platform to stay connected with their university. Likewise, they will be asked their interest in receiving text messages or using a university-based app.

\section{Methodology}

\subsection{Survey Instrument}

The survey was created using the Survey Monkey software. Respondents were instructed to answer the survey questions from the perspective of a "normal" semester rather than a Covid-19 semester. The core of the survey consisted of 12 items. The 12 items were broken into 2 sections. The first section measured whether students used the following modes of communication to stay informed about university news and events: email, the campus newspaper, the campus radio station, the university website, signs around campus, friends, and a campus related GroupMe app. The second section measured the use of social media platforms to stay informed including Twitter, Instagram, Facebook, YouTube, and LinkedIn. These 12 items were measured using 5-point, "Strongly Disagree" to "Strongly Agree" Likert statements.

Three additional items measured student interest in receiving campus updates via text messages, short video messages, and SnapChat. These items were measured on a 5-point "Very Disinterested" to "Very Interested" scale. Their interest in a campus app was also measured. The app was described and then students were asked how likely they would be to use the app. This item was measured on a 4-point scale where 1 was "Very Unlikely" and 4 was "Very Likely".

\subsection{Data Collection}

The study took place at a publicly-funded, regional state university in the Southeast United States. At the time of the study, full-time student enrollment at the institution was a little over 14,000 students, with $95 \%$ being undergraduate students. The survey was pretested on a small group of students in one of the researcher's classes. Once the survey was finalized, the Director of Institutional Research used SPSS to randomly select 2500 students from the student registration database. Google limits the number of emails that can be sent from a single account in a day to 2000. For this reason, the first 1250 students on the list received the email cover letter on one day and the next 1250 students were sent the email on the next school day. The email contained a link to SurveyMonkey survey. After a delay by a few days due to a weather-related event, a reminder email was sent out to solicit a greater response. Data was collected in late October to early November of 2020.

\section{Results}

Three-hundred and thirteen students completed the survey. The sample consisted of $73.5 \%$ females and $25.6 \%$ males. At this university, like other universities, the student population is skewed towards the female gender (approximately 62\%). Furthermore, there is evidence that gender impacts survey response rates in general. Women are more likely to participate in survey research than men [38]. The class standing distribution for the sample was close to the class standing distribution of the university with Freshman being slightly underrepresented while Seniors and 
Graduate students were slightly overrepresented. The various colleges on campus were all represented. Most students were between the ages of 18 and 24 years of age ( $80.4 \%$ of the sample).

\subsection{Communication Modes Utilized}

Figure 1 (Communication Modes Used) plots the percentage of students who indicated that they either "agreed" or "strongly agreed" that they use the various modes of communication. By far, the most popular way of keeping up with university news and events is email as indicated by $98.5 \%$ of the sample. The campus website and signs around campus were also popular ways to abreast of university news. If students are going to use a social media platform to follow the university, they prefer Instagram over the other platforms. They also use the GroupMe app which would mean they are getting information from other students rather than the university. The more traditional forms of communication such as the campus newspaper and radio station were not utilized.

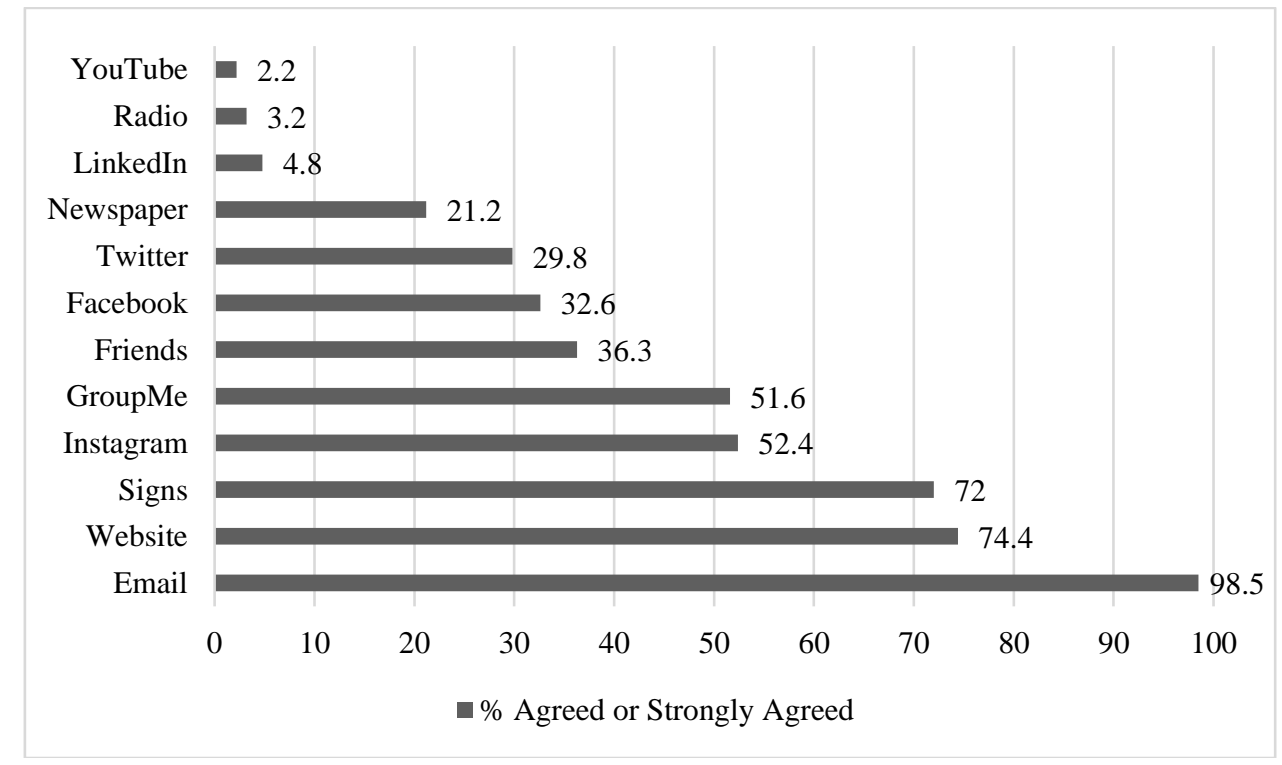

Figure 1. Percentage of Students Agreeing That They Use Each Communication Modes

The responses to the 12 items measuring the use of various communication modes were also ranked by their mean scores as seen in Table 1 (Mean Scores of Surveyed Communication Methods). Looking at the scores, it is again clear that, by far, a majority of the students surveyed check their university email more than any other media. Although, there were some close second place answers which means that there are some alternative ways of contacting students other than email. It seems that a lot of students also check the university website, as well as, read signs posted around campus. The social media platform that the most students said they follow was the university Instagram account. When it comes to the least effective way to reach students according to the survey, YouTube, LinkedIn, and the campus radio station are all pretty closely tied for last. 
International Journal of Managing Public Sector Information and Communication Technologies (IJMPICT) Vol. 12, No.1, March 2021

Table 1. Mean Scores of Surveyed Communication Methods

\begin{tabular}{|l|l|l|}
\hline \multicolumn{1}{|c|}{ Item } & Mean Score & Standard Deviation \\
\hline University email & 4.77 & .58 \\
\hline University website & 3.72 & 1.13 \\
\hline Signs around campus & 3.67 & 1.03 \\
\hline University related GroupMe & 3.12 & 1.5 \\
\hline Instagram & 3.09 & 1.61 \\
\hline Rely on friends & 2.85 & 1.22 \\
\hline Facebook & 2.57 & 1.56 \\
\hline Twitter & 2.37 & 1.51 \\
\hline Campus newspaper & 2.36 & 1.12 \\
\hline LinkedIn & 1.58 & .89 \\
\hline Campus radio & 1.54 & .79 \\
\hline YouTube Channel & 1.52 & .77 \\
\hline
\end{tabular}

\subsection{Communication Modes Desired}

Students were also asked how interested they were in receiving text messages or short video messages and in using the SnapChat app to stay connected with the university. Students were most interested in receiving text messages (Mean $=3.72$, Std Dev $=1.21$ ). While SnapChat had a higher mean score than Video Messages (2.66 for SnapChat versus 2.47 for Video Message), it also had great variability as indicated by the standard deviation (1.47 for SnapChat versus 1.22 for Video Messages). Figure 2 (Interest in Communication Modes) shows the percentage of students who indicated their degree of interest in the three modes of communication. The interest level for text messages was definitely skewed towards the positive side. The interest level for video messages and the Snapchat app showed a great deal more diversity of responses. 
International Journal of Managing Public Sector Information and Communication Technologies (IJMPICT) Vol. 12, No.1, March 2021

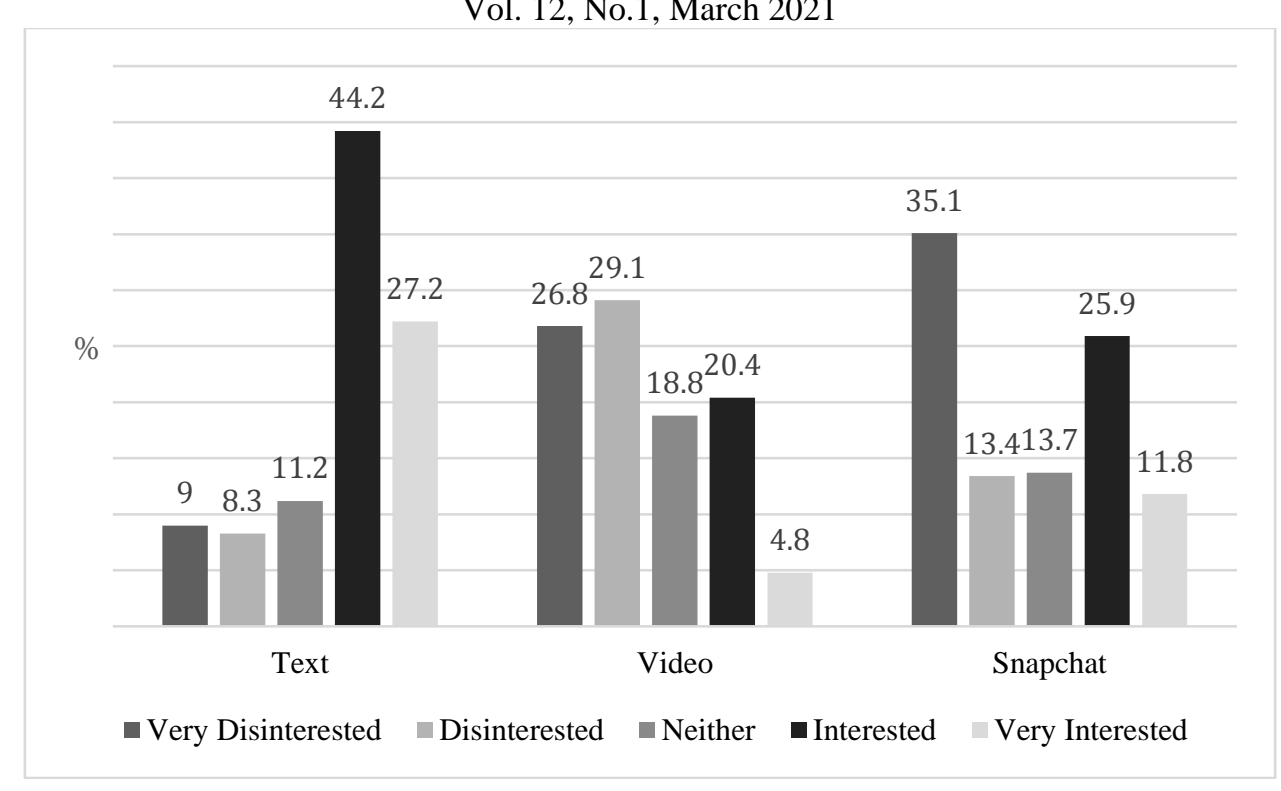

Figure 2. Reported Percentage of Students Level of Interest in Communication Modes

With respect to using an app to keep up with university news and events, students were extremely interested in this possibility, as can be seen in Figure 3 (Likelihood of Using an App). Seventythree percent of the respondents said that they would be "very likely" to use the app. An additional $22.8 \%$ said they would be "likely" to use the app. Collectively, that means that nearly the entire sample (96.2\%) indicated that they would use the app. This item was measured on a 4-point scale and the mean score was 3.68 with a standard deviation of .6 indicating a high level of interest with little diversity in responses.

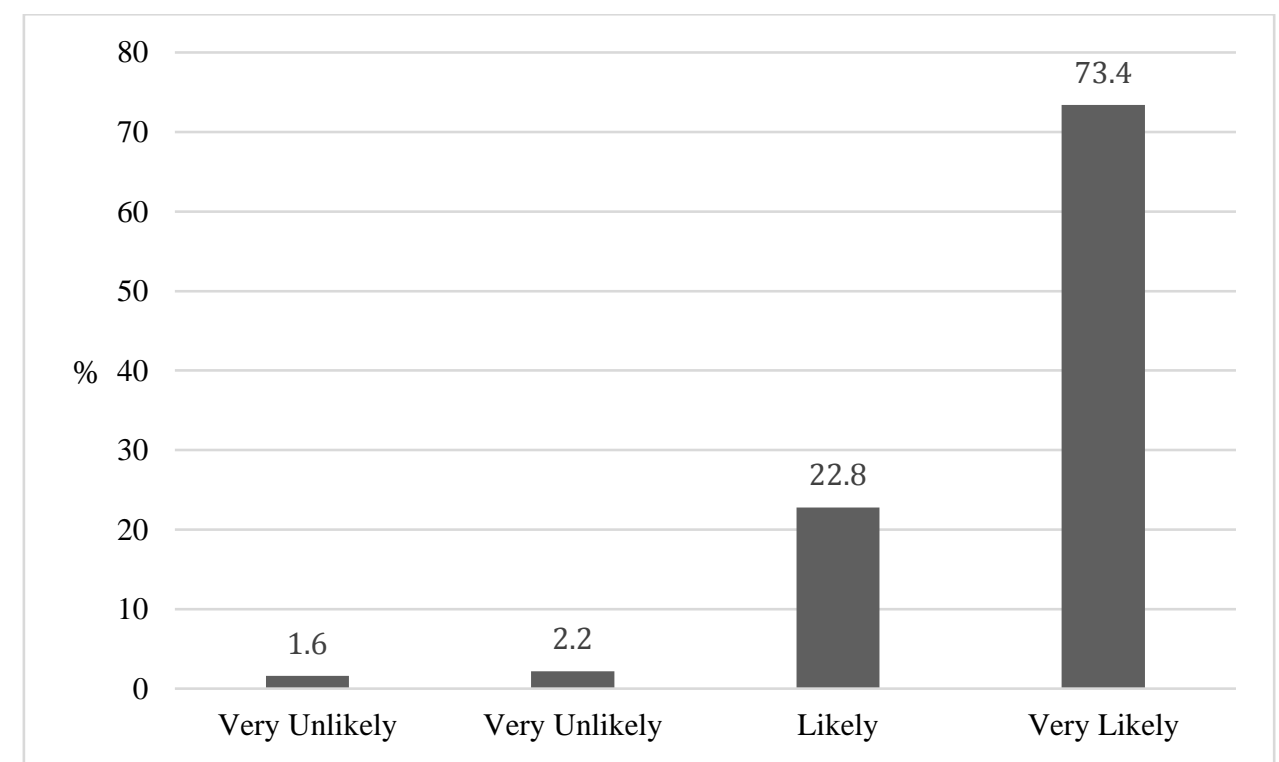

Figure 3. Percentage of Students Reporting Likelihood of Using an App 


\section{Discussion and Limitations}

\subsection{Discussion}

This paper is important because it helps bring clarity to the university on how to communicate with Gen $Z$ students with respect to campus news and events. In this work, we surveyed the communication preferences of Gen Z college students. While the literature suggests that Gen Z are not fond of email as a communication method, when it comes to campus correspondence this was the most popular way of keeping up with university and campus events. Students may very well monitor e-mail when they realize that important information is being delivered in that way even if it is not a preferred method. Students also check the university website as an alternative to checking their email. Although it is far from being high tech, signs around campus may be somewhat effective at getting the word out about campus events. The most popular social media platform was Instagram. Traditional campus media like the campus newspaper and radio station were not frequently used by Gen $\mathrm{Z}$ students.

We learned that students are interested in opting into a text messaging system separate from the emergency systems that most universities currently have in place. They reported being either interested or very interested in such a system. This may be a viable way to get the word out about important university information because one can assume that students always have their phones on them and won't miss a text. We also learned that students are very interested in the creation of a university app that will allow them to connect with the university and read about important things going on. Gen $\mathrm{Z}$ has been known to be mobile and app native so it makes sense for universities to meet them where they spend time. They also used apps like GroupMe to stay connected to other students. The university can encourage these types of connections as this may be an additional avenue for word-of-mouth to occur amongst the student body. GroupMe groups could be created for such groups as campus organizations, dorm living, majors, recreational sports teams, to name a few.

This study does not suggest neglecting social media platforms. For one, a university has other stakeholders that they try to reach and different social media platforms tend to target different demographics. Interestingly, a popular platform among young people is the Snapchat app. In this survey, students were not interested in connecting to the university using this app. It may be that there are certain communication modes that are reserved for close friends and family. It is also not suggested that traditional campus media be abandoned. Again, campus newspapers and radio stations may serve other purposes besides communication to students such as a training ground for broadcast and media production students. This study attempted to bring to light which modes of communication were be most effective and efficient in reaching students about non-instructional content.

\subsection{Limitations}

This study took place at one public university in the southeast region. There may be different results found for private institutions and public universities in other regions. This study also took place during times when Covid restrictions were in place. This may or may not affect the results when, and if, institutions return to more normalcy. At the time of the study, the university did not have a non-emergency texting system nor an app in place. If there were such a platform available, it is yet to be determined if email would still be the most popular communication mode. More seriously, the survey was sent out via email. Therefore, it is possible that students who responded are students who check their email more regularly than the non-respondents of the study. Future research should consider mixed modes of survey distribution. Despite these limitations, this study 
International Journal of Managing Public Sector Information and Communication Technologies (IJMPICT) Vol. 12, No.1, March 2021

may provide some insight as to how to best communicate with Gen Z students regarding university news and events that take place outside the context of the classroom.

\section{REFERENCES}

[1] M. Dimock. "Defining generations: Where Millennials end and Generation Z begins." https://www.pewresearch.org/fact-tank/2019/01/17/where-millennials-end-and-generation-z-begins/ (Accessed January 4, 2021).

[2] Seemiller, C. \& M. Grace (2016) Gen Z Goes to College, John Wiley \& Sons

[3] "Survey: College media continue despite pandemic." http://www.collegemedia.org/news/college_media_review/ (accessed January 4, 2021).

[4] B. Basile. "College Student Media Consumption Survey." https://www.oncampusadvertising.com/wpcontent/uploads/2016/11/College-Student-Media-Consumption-Survey-Spring-2016.pdf (Accessed January 5, 2021).

[5] A. Watson. "Gen $Z$ consumption sources in the U.S. 2020." https://www.statista.com/statistics/1124119/gen-z-news-consumption-us/ (accessed January 5, 2021).

[6] "College Radio Stations." https://radio-locator.com/cgi-bin/finder?format=col\&sr=Y\&s=R (accessed January 5, 2021).

[7] "Survey: College media continue despite pandemic." http://www.collegemedia.org/news/college_media_review/ (accessed January 5, 2021).

[8] “Radio's Roadmap to Gen Z Listenership.” https://www.edisonresearch.com/radios-roadmap-to-genz-listenership/ (accessed January 5, 2021).

[9] "Survey: College media continue despite pandemic." http://www.collegemedia.org/news/college_media_review/ (accessed January 5, 2021).

[10] A. Watson. "Gen $Z$ consumption sources in the U.S. 2020." https://www.statista.com/statistics/1124119/gen-Z-news-consumption-us/ (accessed January 5, 2021).

[11] S. Langmead. "How college websites influence students' web experience." https://www.ecampusnews.com/2013/03/21/how-college-websites-influence-students-webexperience/ (accessed January 5, 20210

[12] E. Loveland. "Instant Generation." https://www.nacacnet.org/news--publications/journal-of-collegeadmission/instant-generation/ (accessed January 5, 2021).

[13] "Human Connection Matters to Gen Z: Ooma Survey Busts Myths Around Generational Communication $\quad$ Preferences," https://www.globenewswire.com/newsrelease/2019/06/26/1874416/0/en/Human-Connection-Matters-to-Gen-Z-Ooma-Survey-Busts-MythsAround-Generational-Communication-Preferences.html (accessed January 5, 2021).

[14] Seemiller, Corey \& Meghan Grace (2016) Gen Z Goes to College, John Wiley \& Sons.

[15] "The Ultimate Guide to Marketing to Gen Z." https://www.campaignmonitor.com/resources/guides/guide-to-gen-Z-marketing-2019/ ） (accessed January 5, 2021).

[16] "Read and Unread." https://www.insidehighered.com/news/2016/03/02/study-explores-impact-socialmedia-texting-email-use (accessed January 5, 2021).

[17] Chang, C., B. Hurst, \& A. McLean. "You've Got Mail: Student Preferences of Instructor Communication in Online Courses in an Age of Advanced Technologies." https://pdfs.semanticscholar.org/6a72/6b9ed6f03d732ecae56dfd360f6b1c8dedf9.pdf _ (accessed January 5, 2021).

[18] Swanson, J.A., S. Renes, \& A. Strange. "The Communication Preferences of Collegiate Students." https://eric.ed.gov/?id=ED600613 (accessed January 5, 2021).

[19] Beck. L \& A. Wright. “iGen: What You Should Know about Post-Millennial Students.” https://wwwproquestcom.ezproxy.selu.edu/docview/2187373935/fulltextPDF/A51E7F1182AD4F6APQ/1 ?accountid=137 72 (accessed January 5, 2021).

[20] Seemiller, Corey \& Meghan Grace (2016) Gen Z Goes to College, John Wiley \& Sons.

[21] Anderson, M. \& J. Jiang. "Teens, Social Media \& Technology 2018." https://www.pewresearch.org/internet/2018/05/31/teens-social-media-technology-2018/ (accessed January 5, 2021). 
International Journal of Managing Public Sector Information and Communication Technologies (IJMPICT) Vol. 12, No.1, March 2021

[22] J. "The Key to Gen $Z$ is Video Content." https://www.forbes.com/sites/jessicabaron/2019/07/03/the-key-to-gen-z-is-videocontent/?sh=31550b423484 (accessed January 5, 2021).

[23] J. Hughes. "Communicating with Generation Z: Everything You Need to Know." https://www.keystoneacademic.com/news/communicating-with-generation-Z-everything-you-needto-know (accessed January 5, 2021).

[24] “Why Generation Z Loves YouTube.”. https://medium.com/@the_manifest/why-generation-z-lovesyoutube-ec64643bd5b2\#: :text=Z\%20in\%202019. ,Why\%20Generation\%20Z\%20Prefers\%20YouTube,clear\%20separation\%20between\%20the\%20two (accessed January 5, 2021).

[25] S. Overland. "New Research Finds YouTube, Video Drives Generation Z Learning Preference." https://www.pearson.com/news-and-research/announcements/2018/08/new-research-finds-youtube-video-drives-generation-z-learning-p.html (accessed January 5, 2021).

[26] M. Anderson. "Understanding Gen Z through the lens of YouTube." https://www.thinkwithgoogle.com/marketing-strategies/video/gen-z-and-youtube/ (accessed January $5,2021)$

[27] M. Tocci. "What You Need to Know About Marketing to Gen Z." https://simpletexting.com/whatgeneration-Z-marketing-trends-do-you-need-to-know-about/ (accessed January 5, 2021).

[28] E. Loveland. "Instant Generation.” https://www.nacacnet.org/news--publications/journal-of-collegeadmission/instant-generation/ (accessed January 5, 2021).

[29] Seemiller, Corey \& Meghan Grace (2016) Gen Z Goes to College, John Wiley \& Sons, pg 58.

[30] B. Murphy. "Millennials and Gen Z Would Rather Text Each Other Than Do This, According to a New Study." https:/www.inc.com/bill-murphy-jr/millennials-gen-z-prefer-texting-to-humanconversations-new-study-says-plus-5-other-findings.html (accessed January 5, 2021).

[31] "Read and Unread." https://www.insidehighered.com/news/2016/03/02/study-explores-impact-socialmedia-texting-email-use (accessed January 5, 2021).

[32] M. Colpitts. "Emergency Notifications Texting, and the FCC." https://www.involvio.com/blog/emergency-notifications-texting-and-the-fcc (accessed January 6, 2021).

[33] "How Colleges Use Texting to Increase Student Enrollment and Improve Retention." https://www.truedialog.com/how-colleges-use-texting-to-increase-enrollment-and-improve-retention/ (accessed January 6, 2021).

[34] Castleman, B. \& L. Page. "Parental Influences on Postsecondary Decision Making: Evidence from a Text Messaging Experiment.” https://journals.sagepub.com/doi/10.3102/0162373716687393 (accessed January 6, 2021).

[35] D. Handova. "3 Ways Mobile Apps Improve Student-Professor Communications." https://www.vonage.com/resources/articles/ways-mobile-apps-improve-student-professorcommunications/ (accessed January 6, 2021).

[36] Walsh, K. “Apps improve campus communications.” https://universitybusiness.com/apps-personalizecampus-communications/ (accessed January 6, 2021).

[37] Hoff, J. "Engaging Students with a Mobile App." https://er.educause.edu/articles/2015/3/engagingstudents-with-a-mobile-app (accessed January 6, 2021).

[38] Smith, W. "Does Gender Influence Online Survey Participation? A Record-Linkage Analysis of University Faculty Online Survey Response Behavior.” https://eric.ed.gov/?id=ED501717 (accessed February 15, 2021). 